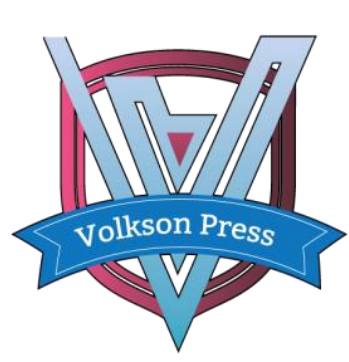

Contents List available at VOLKSON PRESS

Economics \& Management Innovations(EMI)

DOI : http://doi.org/10.26480/icemi.02.2018.26.29

ISBN: 978-1-948012-14-0

\title{
FROM LOCAL IT SUPPORT TO FEDERATED MISSION NETWORKING - EVOLUTION OF NATO APPROACH TO IT PROVISION/DELIVERY
}

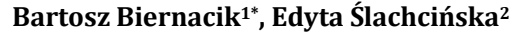 \\ ${ }^{1}$ War Studies University, Warsaw, Poland, al. gen. A. Chruściela „Montera” 103, 00-910 Warszawa-Rembertów, Poland \\ ${ }^{2}$ WSB Universities, ul. Powstańców Wielkopolskich 5, 61-895 Poznań, Poland \\ *Corresponding Author email: b.biernacik@akademia.mil.pl
}

This is an open access article distributed under the Creative Commons Attribution License, which permits unrestricted use, distribution, and reproduction in any medium, provided the original work is properly cited.

\section{ARTICLE DETAILS}

\section{Article History:}

Received 26 June 2018 Accepted 2 July 2018

Available online 1 August 2018

\begin{abstract}
Differences in approach to IT support within one of the most important organization is astonishing. Within less than two decades it had transformed from local support based on a local IT components and local policies of support as well as local standards throughout the one consolidated approach based on a best practices taken from commercial market - ITIL, where IT support started to be defined for a whole organization, services became clearly defined, used had become the most important in the chain of support, standards became common for the NATO - not for one Headquarter from NATO, finishing on a FMN - environment in which exchange of information within allied forces is possible in a real time... these are the most important changes taking place in front of our eyes. The approach to the IT support and usage had finally changed from situation in which IT was treated as some kind of a less important tool to improve the way of day-to-day work to the main solution/environment that gives possibility to rapidly improve the availability of knowledge everywhere it is needed in a time. That knowledge nowadays may mean thousands of lives of people if we take into consideration kind of activity that NATO is prepared for. Therefore, there is a strong need to keep the direction of implementation the latest solutions to permanently improve IT within military organization. That is also very interesting to take lessons learned from that kind of organizations and try to adjust them to civilian environment.
\end{abstract}

\section{KEYWORDS}

IT, IT support, ITIL, Federated Mission Networking.

\section{INTRODUCTION}

IT had become important for almost every aspect of activity in our current lives. If we compare today and for example end of XX century the huge increase of IT usage is visible almost everywhere. To mention at least Internet of Things and IT support even in our day-to-day live like navigation in shoes.... So, we may say that IT is today everywhere. And if so we have to somehow control it.

The same idea was the trigger to implement changes into the organizations at the beginning of XXI century in NATO - one of the biggest organization that need to be supported by IT solutions. Symptoms of the bad organization of IT support within NATO were visible from couple of years and the problem grown for a long time.

\subsection{Source of problem}

Why the IT support become insufficient in NATO? To answer that question, we need to understand the big picture of the North Atlantic organization. Within the NATO countries there are located headquarters which are as a military organization in clearly defined hierarchy. In the past (XX century) IT support was quite a little part of the activity of the organization and was playing second or maybe even third role on the priority list of the importance. As the CIS systems become more and more important in a daily business the headquarters become implementation of local IT specialists' sections, branches, divisions.

Their responsibility was to support local headquarter with the IT solutions. That was the local activity and did not enter on a higher level. As a result, after couple of years the IT standards used in NATO become a very long list of different programs, applications, systems as well as hardware providers. If the activity within one command was not a major problem, the exchange of data between different databases became more and more difficult. IT is supporting teams of specialists had become bigger and bigger There was a need to decide if the approach is still economically efficient and wheatear there is a way to conduct the job better.

\section{NATO PRAGUE SUMMIT IN NOVEMBER 2002}

First decision of milestone change in NATO in IT support was taken in 2002 during the NATO Prague Summit. On November 21-22, 2002, the NATO allies met in as it was called "Transformation" summit in Prague. They sought to culminate allied efforts to change from a military alliance geared for conflict against the Soviet Union to a more flexible alliance with new capabilities for new threats. They opened the door to democratic candidate states and agreed to a forward-looking program for partnership countries able to contribute to security.

What was the most important during this summit was the decision taken about the reorganization of NATO structures. As we can read in Prague Summit Declaration issued by the Heads of State and Government in point 4.b.: Streamline NATO's military command arrangements. We have approved the Defense Ministers' report providing the outline of a leaner, more efficient, effective and deployable command structure, with a view to meeting the operational requirements for the full range of Alliance missions. It is based on the agreed Minimum Military Requirements document for the Alliance's command arrangements. The structure will enhance the transatlantic link, result in a significant reduction in headquarters and Combined Air Operations Centers, and promote the transformation of our military capabilities.

There will be two strategic commands, one operational, and one functional. The strategic command for Operations, headquartered in Europe (Belgium), 
will be supported by two Joint Force Commands able to generate a landbased Combined Joint Task Force (CJTF) headquarters and a robust but more limited standing joint headquarters from which a sea-based CJTF headquarters capability can be drawn. There will also be land, sea and air components. The strategic command for Transformation, headquartered in the United States, and with a presence in Europe, will be responsible for the continuing transformation of military capabilities and for the promotion of interoperability of Alliance forces, in cooperation with the Allied Command Operations as appropriate. We have instructed the Council and Defence Planning Committee, taking into account the work of the NATO Military Authorities and objective military criteria, to finalise the details of the structure, including geographic locations of command structure headquarters and other elements, so that final decisions are taken by Defence Ministers in June 2003 [1].

Another important declaration was put in point 16th of the declaration: As NATO transforms, we have endorsed a package of measures to improve the efficiency and effectiveness of the headquarters organisation. The NATO+ Initiative on human resources issues complements this effort. We are committed to continuing to provide, individually and collectively, the resources that are necessary to allow our Alliance to perform the tasks that we demand of it [1]. The Heads of State mention also (in point 4.f.) for the first time that clearly that: NATO needs to strengthen capabilities to defend against cyber-attacks.

\section{STRUCTURAL CHANGES IN NATO - DIFFERENT APPROACH TO IT SUPPORT}

Since that summit NATO started to change its approach to IT support. At the same time when the commands structure was redefined the same happened with the IT support within the NATO. In order to do it in accordance with the latest trends in civilian part of the world there was a decision taken to use ITIL methodology. This solution is used by plenty of commercial organizations like: Coca-Cola, Microsoft and many more. ITIL gives possibility to create certain skeleton of the organization delivering widely comprehended services. It lets the organization for the adaptation of requirements of methodologies to the specificity of the environment, in which the one is acting (e.g. army). However, an essential transparency isn't being lost at the information exchange among organizations. Within NATO there was a second version of ITIL methodology used.

Reorganization of NATO structures resulted creation of NCSA (NATO CIS Support Agency) which since 2004 was responsible for IT support within NATO in accordance with ITIL methodology. Since then local IT teams had become a part of a bigger organization that were under control on few levels - thank to this one common for the whole NATO approach as well as standards of hardware and software was implemented. Every headquarter started to use the same standardized applications, standards and IT systems. Problems with different approach to the IT support was minimalized.

What needs to be mention is that the implementation of ITIL in NATO gave some benefits, which includes: - increased user and customer satisfaction with IT services; - improved service availability, directly leading to increased business profit sand revenue; - financial savings from reduced rework, lost time, improved resource management and usage; - improved time to market for new products and services; - improved decision making and optimized risk.
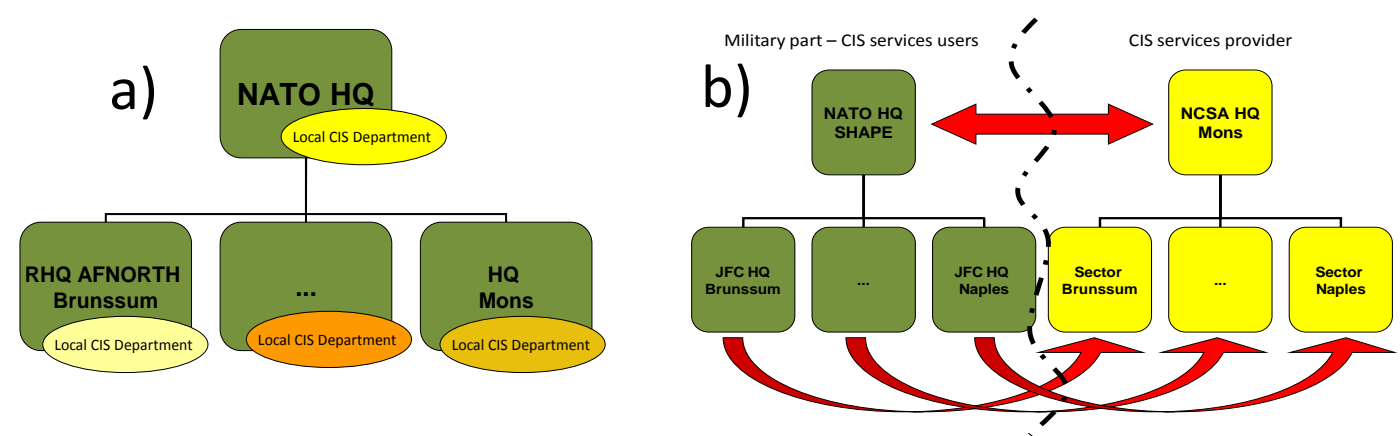

Figure 1: Structure of NATO IT support - a) before the changes (visible local IT support departments in each headquarter) and b) changes in structure creation of NCSA - IT services provider (up to 31.06.2012) Source: [2].

This focus is a major factor in ITIL's worldwide success and has contributed to its prolific usage and to the key benefits obtained by those organizations deploying the techniques and processes throughout their organizations.

NCSA as a new organization was responsible to provide core tasks, such as: - operating, maintaining, controlling and administering the central components of NATO's networks, providing coverage of mission essential systems 24 hours a day, 7 days a week; - providing strategic and policy advice to headquarters' leadership to ensure the efficient and effective use of CIS resources; - providing secure and non-secure computer, telephone and video conference services to NATO's static headquarters; - ensuring the compatibility of new CIS hardware and software on NATO's networks; - providing technical advice; - installing computers, telephone and video conference equipment; - conducting hardware and software maintenance; - configuring and controlling networks; and providing training for personnel on NATO communication and information systems.

\section{NATO NETWORK ENABLE CAPABILITY}

As the approach to the IT support changed the same happened with the IT itself. It evaluates permanently with the speed that can be hardly compare to any other area of life. Things impossible a decade ago are common for all of us today. This grow in capabilities was used also in military environment to increase possibility of CIS systems supporting the activity of armed forces in war theatre. New very sophisticated systems were created which gave a chance to share the information within the allied forces in a real time. That chance resulted a change in theory of warfare (or we may say - the theories created thousands years ago was finally possible to realize in life). The importance of information during the conducting war was emphasized by Sun Tzu in Vth century B.C. [3].

The answer to the possibility of implementation this new approach was in U.S.A. Network Centric Warfare (NCW) theory described by couple of researches [4,5]. It describes the possible usage of IT capabilities in modern warfare and shows how to combine all the possibilities into the synergy effect of used joint forces in the battlefield. The answer of this American theory was creation of NATO program - NATO Network Enable Capability (NNEC).

At the Prague Summit in November 2002, NATO recognized that transformation of the military based upon Information Age principles was essential and pursued a course of transformation denoted as NATO Network-Enabled Capabilities (NNEC). In November 2003, nine NATO nations (Canada, France, Germany, Italy, The Netherlands, Norway, Spain, The United Kingdom and The United States) signed an arrangement to join in funding a feasibility study on NATO Network Enabled Capability (NNEC) as an important step towards NATO transformation. The study was carried out by the NATO C3 Agency (NC3A). In 2009, the ACT launched an awareness campaign within NATO, as well as in NATO Nations and beyond, to promote the NNEC concept and have it adopted NATO-wide. Achieving full collaboration and full coherence between the various NATO and NATO Nations projects is the long-term goal.

In response to the measures agreed at Prague, the NATO Strategic Commanders (SCs) have developed a set of "Transformational Goals" and "Transformational Objective Areas" (TOAs) (Figure 3) to support the 
development of capable future forces that are able to undertake the future missions of the Alliance. One of the key TOAs identified by the SCs is Network Enabled Capability (NEC). This capability, as described by the SCs, involves the linking together of sensors, decision makers, and weapon systems, as well as multinational military, governmental, and nongovernmental agencies in a seamless, collaborative, planning, assessment and execution environment. The NEC must provide for the timely exchange of secure information, utilizing communication networks which are seamlessly interconnected, interoperable and robust, and which will support the timely collection, fusion, analysis and sharing of information [6].

NNEC enables dynamic battle command, that is to say, through the federation of key command, control and support capabilities, sharing information in real time, NATO commanders will have unparalleled situational understanding facilitating effective engagement in a comprehensive approach. The basis of the comprehensive approach is typified by the NNEC slogan: Share to Win. Everyone must have a "share" mentality which will be essential in implementing the idea of the program. NNEC may be described as: people, processes, and then technology people first, then processes, and finally technology It is these capabilities which include how people interact with each other, processes or doctrine for conducting business, and how to better use current and future technology.

In more simple terms, NNEC can be considered as the ability to effectively federate capabilities in coalition operations, by addressing not only the networks and systems, but also the information to be shared, the process employed to handle it, and the policy and doctrine that allows sharing information and services. The need for NNEC is intrinsic to all coalition operations. NNEC Supports heterogeneous partners, with different capabilities and needs, to operate under a federate set of "rules" that provide interoperability from the technical to the cognitive domain. NNEC fully supports "The Connected Forces Initiative" which, in the words of the NATO Secretary General "mobilizes all of NATO's resources to strengthen the Allies' ability to work together in a truly connected way" [6].

The Networking and Information Infrastructure (NII) is the supporting structure that enables collaboration and information sharing amongst users and reduces the decision-cycle time. This infrastructure enables the connection of existing networks in an agile and seamless manner. This leads to Information Superiority, which is the ability to get the right information to the right people at the right time. NATO defines information superiority as the operational advantage derived from the ability to collect, process, and disseminate an uninterrupted flow of information while exploiting or denying an adversary's ability to do the same.

For disparate systems to work together, NATO has traditionally focused on interoperability. NNEC picks up from there and through the four components identifies requirements, guidelines and solutions that will allow effective sharing of information and services supported by standards, joining instructions, data management practices, adequate information assurance and commensurate policies. NNEC looks at the ability to exchange information and, more importantly, at the ability to exploit that information, addressing the non-technical aspects of interoperability in the process [7].

The NNEC program provides various benefits to all levels, military and civilian. Some of these benefits are: - improved efficiency; - drastic increase in interoperability between nations; - improved and secure way of sharing information; - better information quality; - faster decisions and speed of command [8].

\section{FURTHER TRANSFORMATION OF NATO STRUCTURE - CREATION OF NATO COMMUNICATION AND INFORMATION AGENCY NCI}

Implementation of ITIL in version 2 in 2004 into the NATO did not accomplished the transformation of structures of IT supporting organization. In $2007 \mathrm{new}$, 3rd version of ITIL was published on a civilian market. The ITIL library, in the third version, is based on the lifecycle of the website (service) provided to the user and currently consists of the following five phases $[9,10]$ : 1 . Service Strategy (SS) ; 2. Service Design (SD) ; 3. Service Transition (ST) ; 4. Service Operation (SO) ; 6. Continual Service Improvement (CSI) .

As a result, in NATO it was also implemented - since 1st July 2012 NCSA was deactivated and in its place NATO Communication and Information
Agency NCI was created. Its structure was created in accordance to the latest, updated approach of IT support within organization.

\section{FEDERATED MISSION NETWORKING}

NATO is active since last couple of years in Afghanistan. Its mission ISAF was established in the beginning of XXI century. Since then there was a strong need to create common IT platform to exchange data in a real time with all the allies nations. That was the beginning of implementation the Afghan Mission Network (AMN) [11]. That was the beginning of creation new in NATO environment to share the information - common network ready

to be used everywhere in the world with clearly defined services. Later, as a lessons' learned, there was a decision taken to create unique environment for the whole NATO, based on the experience form AMN Federated Mission Networking (FMN) and on the NATO Network Enabling Capability Program.

FMN is a key contribution to the Connected Forces Initiative (CFI), helping Allied and Partner forces to better communicate, train and operate together. FMN enables a rapid instantiation of mission networks by federating NATO organizations, NATO Nations and Mission Partner capabilities, thereby enhancing interoperability and information sharing. Federated Mission Networking is a governed conceptual framework consisting of people, processes and technology to plan, prepare, establish, use and terminate mission networks in support of federated operations [12].

FMN is a capability aiming to support command and control and decisionmaking in future operations through improved information-sharing. It provides the agility, flexibility and scalability needed to manage the emerging requirements of any mission environment in future NATO operations. FMN is based on principles that include cost effectiveness and maximum reuse of existing standards and capabilities [12]. It consists of three elements: 1. Federated Mission Networking Governance; 2. Federated Mission Networking Framework; 3. Mission Networks.

FMN governance sets objectives, defines the regulatory framework and environment (rules, procedures, policies, standards etc.) and helps ensure responsible use of resources and management of risk. Executed by the Military Committee, the governance level provides direction for the supporting management bodies executing management functions for the FMN Framework and for each Mission Network and for the FMN Affiliates.

The management level translates the direction provided by the Military Committee into strategies and plans, which in turn are translated into action by Federated Mission Networking Affiliates. The performance is reported back to the governance level, who subsequently evaluates the performance and incorporates it in adjustment of expectations. The working groups constitute mutually supporting and complementary Federated Mission Networking assets, empowered to liaise directly with other NATO bodies and entities and the native organizations of affiliates as required [12].

The Federated Mission Networking Framework is a governed, managed, all-inclusive structure providing a permanent ongoing foundation with processes, plans, templates, enterprise architectures, capability components and tools needed to prepare (including planning), develop, deploy, operate, evolve and terminate Mission Networks. It includes four major processes: 1. Initiate and Join the FMN Framework; 2. Govern and Manage Federated Mission Networking Capability; 3. Maintain Federated Mission Networking-Ready Forces; 4. Instantiate and Manage a Mission Network Instance.

Mission Networks provide a governed single instance of capability, including the Communication and Information Systems, management, processes and procedures created for the purpose of an operation, exercise, training event, or interoperability verification activity. FMN is instantly improving its capabilities and provided services for its potential users. Within the FMN there were basic and advanced IT services defined, available for the end operator. To be able to exchange more data with the dedicated IT systems there were additional services created, called Functional Area Services (FAS). To mention only the most common: 
1. Situational Awareness Service implemented by the following products: NCOP (NATO Common Operational Picture) IGeoSIT (NATO interim Geospatial Situation Intelligence Tool).

2. C2 Planning Service implemented by the following products: TOPFAS (Tools for Operations Planning Functional Services) NCRS (NATO Crisis Response System).

3. C2 Collaboration Service), implemented by JChat (Joint Chat).

4. Operational Reporting Service implemented by JOCWatch (Joint Operations Centre Watch).

5. Joint Targeting Service implemented by JTS (NATO Joint Targeting System)

6. Land C2 Information Service implemented by LC2IS (Land C2 Information System).

7. Intel Applications Support Service, implemented by the following products: a. NITB (NATO Intel Toolbox); b. JOIIS Uoint Ops/Intel Information System); c. ANB (Analyst Notebook); d. INTEL FS (INTEL Functional Services).

Four graduated levels of capability are defined that provide options for the participation in the evolution of the Federated Mission Networking Capability in general, and the participation in Mission Networks in particular [12]: 1. a Mission Network Element contains Networking and Information Infrastructure and services for self-provisioning, including sufficient mission essential services; 2. a Mission Network eXtension contains infrastructure and services for self-provisioning, but may not include sufficient mission essential services; 3. a Hosted User is a Mission Network participant that is not able to provide infrastructure and services for self-provisioning; 4. other Entities are not integral part of the network, nor are they subject to Federated Mission Networking Framework requirements.

NATO and national engagement in the overall effort and representation in the working groups facilitates collaboration and ensures quality of effort. NATO organizations, NATO and Non-NATO nations are encouraged to become Federated Mission Networking Affiliates, which implies they will maintain and further develop capabilities for federated mission networks and ensure Communication and Information Systems security and interoperability compliance with Federated Mission Networking standards and principles [13,14]. Federated Mission Networking Affiliates will be able to contribute Federated Mission Networking-ready forces to a mission on short notice and with minimal preparation.

\section{REFERENCES}

[1] Alberts, D.S., John, J., Garstka, J.J., Frederick, P.S. 1999. Network Centric Warfare: Developing and Leveraging Information Superiority, 2nd Edition (Revised), Library of Congress Cataloging-in-Publication Data.

[2] Alberts, D.S., John, J., Garstka, J.J., Hayes, R.E., Signori, D.A. 2001 Understanding Information Age Warfare, Library of Congress Catalogingin-Publication Data.

[3] Biernacik, B. 2015. Informatyzacja Sił Zbrojnych RP - przespane szanse?, [w] Ewolucja wojskowych systemów teleinformatycznych oraz lessons learned w świetle misji pokojowych i stabilizacyjnych, Sieradz.

[4] Bon van, J. 2009. Foundation o IT Service Management based on ITIL, Zatlbommel, Van Haren Publishing, (ITSM Library), Van Faren.

[5] Buckman, T. 2005. NATO Network Enabled Capability Feasibility Study. Executive summary: version 2.0, Communications and Information Systems Division, NATO Consultation, Command and Control Agency, October, Retrieved from http://www.dodccrp.org/files/nnec_fs_executive_summary_2.0_nu.pdf, access 28.03.2018

[6] http://www.act.nato.int/nnec

[7] https://www.nato.int/cps/en/natohq/topics_54644.htm

[8] https://c2coe.org/policy-development/fmn/

[9] http://www.act.nato.int/fmn

[10]https://www.eiseverywhere.com/file_uploads/2f6043f27e1576122f 1b3e0319d5b1d8_FromAMNtoFMN-Friedrich.pdf

[11]

http://www.act.nato.int/images/stories/events/2015/fmn/fmn_01.png

[12] Koszlajda A., Zarządzanie projektami IT. Przewodnik po metodykach Helion, 2010

[13] Prague Summit Declaration issued by the Heads of State and Government participating in the meeting of the North Atlantic Council in Prague, Czech Republic, Retrieved from https://www.nato.int/cps/en/natohq/official_texts_19552.htm, access 28th March 2018

[14] Sun Tzu, Art of War, Retrieved from https://suntzusaid.com/ access 28th March 2018 